\title{
Cardiac PDEs and crosstalk between cAMP and cGMP signalling pathways in the regulation of contractility
}

\author{
Finn Olav Levy
}

Received: 5 April 2013 /Accepted: 8 April 2013 / Published online: 7 May 2013

(C) Springer-Verlag Berlin Heidelberg 2013

\begin{abstract}
Elucidation of cAMP and cGMP signalling in the heart remains a hot topic, and new regulatory mechanisms continue to appear. Studying the influence of phosphodiesterases on $5-\mathrm{HT}_{4}$ receptor signalling in porcine atrium, a paper from this issue of the journal expands findings of a crosstalk between cardiac cGMP and cAMP signalling recently discovered in failing rat ventricle to a different species and cardiac region. The overall data suggest that cGMP, produced following stimulation of the NPR-B receptor for C-type natriuretic peptide (CNP), inhibits cAMP degradation by phosphodiesterase 3 and thereby enhances cAMP-mediated signalling from $\beta$-adrenoceptors and 5$\mathrm{HT}_{4}$ receptors to inotropic effects. In porcine atrium, this effect can be seen both as an increase in inotropic effect and as a reduced fade of the inotropic effect with time. Thus, accumulating evidence brings together several active fields of research, including cardiac phosphodiesterases, compartmentation of cyclic nucleotide signalling and the field of natriuretic peptides. If present in human hearts, this effect of CNP may have clinical implications.
\end{abstract}

\section{Introduction}

More than 50 years after the discovery of cAMP as a second messenger (Sutherland and Rall 1958), and almost 50 years after its essential role in the inotropic response to catecholamines was proposed (Robison et al. 1965), the fine-tuning

F. O. Levy $(\bowtie)$

Department of Pharmacology, Faculty of Medicine, University of Oslo and Oslo University Hospital, Sognsvannsveien 20, P.O. Box 1057 Blindern, 0316 Oslo, Norway

e-mail: f.o.levy@medisin.uio.no

F. O. Levy

K.G. Jebsen Cardiac Research Centre and Center for Heart Failure Research, Faculty of Medicine, University of Oslo, Oslo, Norway of this regulatory principle is still the subject of intense investigation. Although it is now clear that pathways independent of cAMP also play a role in the regulation of cardiac contractility, e.g. through regulation of myosin light chain phosphorylation (Rossmanith et al. 1997; Andersen et al. 2002; Grimm et al. 2005; Qvigstad et al. 2005c; Riise et al. 2008; Hussain et al. 2009), cAMP-dependent pathways are still considered the main regulators of cardiac contractility, and new pieces of the puzzle leading to its understanding are still being added. One important reason for this is the realisation that long-term stimulation of this signalling pathway in patients with chronic heart failure leads to increased mortality and, accordingly, that blocking $\beta$ adrenoceptors ( $\beta$-adrenergic receptors, $\beta$-AR), the main receptors that stimulate this pathway, reduces heart failure mortality (Waagstein et al. 1975, 1993; Packer et al. 1996; CIBISII Investigators and Committees 1999; MERIT-HF Study Group 1999; Lohse et al. 2003). Much recent attention has been devoted to the compartmentation of cAMP signalling, and although this concept is now more than 30 years old (Corbin et al. 1977; Kaumann and Birnbaumer 1974; Brunton et al. 1981), substantial advances have been seen during the latest few years, brought about by the development of novel technology to measure cAMP at the subcellular level, e.g., by FRET-based cAMP sensors (Zaccolo et al. 2000; Zaccolo and Pozzan 2002; Nikolaev et al. 2004; Mongillo et al. 2004; Ponsioen et al. 2004; Warrier et al. 2005), combined with thorough pharmacological studies where the focus is on interpreting the complex changes observed in cardiac preparations with the combined use of different stimulators and inhibitors. One such study appears in the present issue (Weninger et al. 2013), which, together with a related study by the same authors last year (Weninger et al. 2012), bring together several recent lines of research that have independently and together contributed to the recent understanding of cAMP regulation of cardiac contractility: the discovery and characterisation of $5-\mathrm{HT}_{4}$ 
receptor-mediated effects in the heart (first in atria, later also in ventricles), the role of different phosphodiesterases in the compartmentation of cAMP and cAMP-mediated effects by limiting diffusion of cAMP, and the recent finding that natriuretic peptides seem to have previously unappreciated effects in the heart by bringing about cGMP-mediated enhancement of cAMP signalling to enhance cardiac contractility (Qvigstad et al. 2010; Afzal et al. 2011b).

\section{Cardiac 5- $-\mathrm{HT}_{4}$ signalling and the roles of various phosphodiesterases}

Weninger et al. $(2012,2013)$ studied the effects of $5-\mathrm{HT}_{4}$ receptors in porcine atria, a well-known system for the study of these receptors (Kaumann 1990), which are also present in the atria of human hearts (Kaumann et al. 1990; Kaumann and Levy 2006a). Early studies suggested an apparent lack of such receptors in porcine (Schoemaker et al. 1992; Saxena et al. 1992) and human (Jahnel et al. 1992; Schoemaker et al. 1993) ventricle, but it was later shown that the use of the non-selective phosphodiesterase (PDE) inhibitor 1-isobutyl-methyl-xanthine (IBMX) could reveal 5- $\mathrm{HT}_{4}$-mediated effects also in porcine and human ventricle (Brattelid et al. 2004). Furthermore, studies in rats with heart failure revealed the appearance of functional $5-\mathrm{HT}_{4}$ receptors in the cardiac ventricle of rats (Qvigstad et al. 2005a), a species where cardioexcitation by serotonin had earlier been thought to be mediated by $5-\mathrm{HT}_{2}$ receptors (Läer et al. 1998). The increased expression of $5-\mathrm{HT}_{4}$ receptors in failing rat cardiac ventricle seems to reflect the re-expression of receptors present in the foetal heart (Brattelid et al. 2012). On the basis that the ventricular $5-\mathrm{HT}_{4}$ receptors showing increased expression in the failing rat and human ventricle signal through cAMP, as do $\beta$-AR, it was proposed that treatment with $5-\mathrm{HT}_{4}$ antagonists could be a useful addition to pharmacological treatment of heart failure (Qvigstad et al. 2005b; Levy et al. 2008). So far, this has been tested in a rat model of heart failure (Birkeland et al. 2007) as well as in a clinical trial on heart failure patients with reduced ejection fraction, receiving the $5-\mathrm{HT}_{4}$ antagonist piboserod for 6 months (Kjekshus et al. 2009). Both studies showed some results consistent with the hypothesis that $5-\mathrm{HT}_{4}$ antagonism may be of benefit in heart failure, but further clinical testing will be required to conclude about the potential clinical usefulness of such treatment (Kjekshus et al. 2009).

One of the classical criteria set out by Sutherland that an effect was indeed mediated by cAMP was that the effect should be enhanced by inhibiting the breakdown of cAMP by phosphodiesterases, typically using the classical PDE inhibitor theophylline (Butcher and Sutherland 1962) and later the non-selective PDE inhibitor IBMX. This criterion was indeed also applied to the cardiac $5-\mathrm{HT}_{4}$ responses, both in porcine atria (De Maeyer et al. 2006) and in porcine, human and rat ventricles (Brattelid et al. 2004; Afzal et al. 2008). Although the initial aim of such studies was to document beyond doubt the involvement of cAMP in the effects of 5-HT, it soon became a question which PDEs could be involved in limiting these responses (Kaumann and Levy 2006b). One important motivation for this was the observation that $5-\mathrm{HT}_{4}$ receptors, at least in the failing rat heart, appeared to give a robust inotropic effect despite a very modest cAMP production compared to $\beta$-AR (Qvigstad et al. 2005a). Further studies were enabled by the developments during the 1990s of the understanding of the multitude of PDE subtypes as well as the availability of PDE subtype-selective inhibitors (see, e.g. Verde et al. 1999) and revealed that 5 - $\mathrm{HT}_{4}$-mediated inotropic responses in failing rat and human ventricles were primarily limited by PDE3 (Afzal et al. 2008). However, whereas no effect of the PDE4-selective inhibitor rolipram alone was observed on the $5-\mathrm{HT}_{4}$-mediated inotropic responses, a further enhancement of the inotropic response by rolipram was observed in the presence of a PDE3 inhibitor (cilostamide), revealing a (secondary) role for PDE4 in limiting the inotropic response both in rat and human failing ventricles (Afzal et al. 2008). Both PDE3 and PDE4 were also found to be involved in the fade of inotropic responses to $5-\mathrm{HT}_{4}$ receptor stimulation in porcine atria (Galindo-Tovar et al. 2009), the tissue studied by Weninger et al. (2012, 2013), whereas in human atria, PDE3 but not PDE4 was observed to be responsible for fade (Galindo-Tovar et al. 2009). Importantly, Galindo-Tovar et al. (2009) revealed differences between porcine atria and ventricles as well as age-dependent changes in porcine atria, indicating that care must be exercised when extrapolating results not only between species but also between cardiac atria and ventricles and even with age.

In this context, it is interesting to relate these findings with the $5-\mathrm{HT}_{4}$ receptor to the large and increasing body of knowledge concerning its better-known relatives, the $\beta_{1^{-}}$ and $\beta_{2}$-adrenoceptors or adrenergic receptors ( $\beta$-AR). It has become clear recently that there are marked differences between $\beta_{1}$ - and $\beta_{2}$-AR-mediated signalling, e.g. in terms of localization of the cAMP produced (Nikolaev et al. 2006), the effects of PDE subtypes on the cAMP produced (Rochais et al. 2006) and the localisation of the receptors (Nikolaev et al. 2010).

These groundbreaking molecular studies, combined with studies on the PDEs regulating the functional effects of $\beta_{1}$ and $\beta_{2}$-AR-mediated effects in different species and cardiac regions, such as human atrium (Christ et al. 2006; Kaumann et al. 2007), rat ventricle (Vargas et al. 2006; Christ et al. 2009; Afzal et al. 2011a), mouse atrium and ventricle (Galindo-Tovar and Kaumann 2008) and human ventricle (Molenaar et al. 2013), are now providing a much better understanding than we had just a few years ago concerning 
the mechanisms by which different stimuli, through the same second messenger-cAMP — can produce different cellular and physiological effects. Although there is still a long way to go because of the complexity of the information obtained, some common patterns seem to emerge: $\beta_{1}$-AR produce a large cAMP signal which reaches large parts of the cell (Nikolaev et al. 2006). When measured as wholecell cAMP or with sensors that are widely distributed, this cAMP signal is mainly limited by PDE4. However, $\beta_{1}$-ARmediated inotropic effects are still primarily limited by PDE3, indicating the co-localisation of certain isoforms of PDE3 with the cAMP regulating the phosphorylations relevant to increase contractility, e.g. PLB and TnI phosphorylation. The results tend to diverge to some extent regarding whether PDE4 achieves an important role once PDE3 is inhibited, a question which may well be of clinical importance in patients using PDE inhibitors. Two main patterns seem to be important in this regard: (1) PDE4 seems to play a relatively smaller role in human compared to rat atrium (Christ et al. 2006 and Kaumann et al. 2007 vs. Christ et al. 2009) and (2) the functional role of PDE4 in the cardiac ventricle seems to be reduced in heart failure, at least in rats (Afzal et al. 2011a). But for the 5- $\mathrm{HT}_{4}$-mediated inotropic response, PDE3 inhibition seems to demask a role of PDE4, both in rat and human failing ventricles (Afzal et al. 2008).

\section{Atrial natriuretic peptides and crosstalk with cAMP-mediated signalling}

The other main line of research addressed by the study of Weninger et al. $(2012,2013)$ is the interference of signalling through natriuretic peptides (ANP, BNP, CNP) and their receptors NPR-A and NPR-B (also known as particulate or membrane-bound guanylyl cyclase GC-A and GC-B) with cAMP-mediated signalling. It was shown by Qvigstad et al. (2010) that CNP, acting through NPR-B, but not ANP or BNP, acting through NPR-A, enhances $\beta_{1}$-AR-mediated signalling in failing rat ventricles through cGMP-mediated (competitive) inhibition of PDE3. This effect is also seen on 5- $\mathrm{HT}_{4}$-mediated inotropic effects in the failing rat ventricle (Afzal et al. 2011b). These findings are now followed up in a different species and cardiac region by studies of CNP effects in the porcine atrium by Weninger et al. (2012 and this issue). In failing rat ventricles, this crosstalk was shown to result in increased inotropic effects of $\beta_{1}$-AR and 5-HT receptor stimulation (Qvigstad et al. 2010; Afzal et al. $2011 \mathrm{~b}$ ), and CNP also promoted $\beta_{1}$-AR-stimulated cardiomyocyte apoptosis similar to the inhibition of PDE3 by cilostamide (Qvigstad et al. 2010). In porcine atrium, the functional effect of CNP was observed both as an increased inotropic response to $5-\mathrm{HT}_{4}$ receptor stimulation and as a reduced fade of the inotropic response with time (Weninger et al. 2012, 2013). Whereas the first study of Weninger et al. (2012) could seem to imply a need for PDE2 inhibition to observe the effect of CNP, this apparent discrepancy with the rat ventricular data was resolved in the second study, where there is clearly no additional role of the PDE2 inhibitor EHNA (Weninger et al. 2013). Whilst the study of Afzal et al. (2011b) found apparently opposite effects of cGMP generated by soluble guanylyl cyclase (sGC) and NPR-B receptor stimulation on the $5-\mathrm{HT}_{4}$-mediated inotropic response in rat failing ventricles, this result could not be confirmed by Weninger et al. $(2012,2013)$ in porcine atrium, who found that sGC stimulation rather seemed to attenuate responses to 5-HT. Whether this apparent controversy reflects a species or tissue difference or may be explained by methodological differences remains to be determined.

\section{Possible clinical relevance of modulatory roles of cGMP}

The field of cGMP-mediated effects in the heart and the potential benefits of enhancing cGMP signalling in heart failure has received some recent attention, the clinical culmination of one line of this research being the disappointing results of the RELAX Study of the PDE5 inhibitor sildenafil in heart failure patients with preserved ejection fraction (a.k.a. diastolic heart failure; Redfield et al. 2013). The story of natriuretic peptides in the heart has many aspects. Clearly, different variants of these peptides or their precursors serve as very useful biomarkers of heart failure based on the increased levels of ANP and BNP and their derivatives in heart failure (Omland et al. 1996). From the assumption that their natriuretic and haemodynamic properties would be beneficial in heart failure, BNP, in the form of nesiritide, has also been used in the treatment of heart failure, initially with promising results (Colucci et al. 2000). But with increasing evidence that the long-term effect of this treatment might not be so beneficial (Yancy 2004; Sackner-Bernstein et al. 2005), the era of their use in heart failure treatment may be reaching an end after the conclusion of the ASCEND-HF trial, showing that treatment of acute decompensated heart failure with nesiritide does not provide any survival benefit (O'Connor et al. 2011). In this context, recent results, including those of Weninger et al. concerning the effects of CNP in the heart, may be of clinical interest. Although nesiritide primarily activates the NPR-A receptor and CNP primarily activates the NPR-B receptor, this distinction may not be absolute, also not in a clinical setting. In light of the beneficial effects of beta-blockers in heart failure and the deleterious effects of enhancing cardiac cAMP-mediated effects in heart failure patients by PDE inhibition (Packer et al. 1991; Cohn et al. 1998), or even by only partial $\beta$-AR stimulation (The Xamoterol in Severe Heart Failure Study Group 1990), the enhancement of cAMPmediated inotropic effects of $\beta_{1}$-AR (Qvigstad et al. 2010) 
and 5-HT $\mathrm{HT}_{4}$ receptor stimulation (Afzal et al. 2011b; Weninger et al. 2012; Weninger et al. 2013) by CNP may prove to be critically relevant for the absence of the expected beneficial effects of using BNP in heart failure treatment.

\section{Perspectives}

It remains to be seen whether the cGMP-mediated inhibition of PDE3 so far reported in rat ventricle and porcine atrium is also present and of significance in the human heart. If so, it could be of interest to determine whether blocking this effect of CNP will be of benefit in heart failure treatment. Perhaps treatment with a natriuretic peptide, like nesiritide, could be combined with a selective NPR-B receptor antagonist to eliminate these newly reported cardiac effects of natriuretic peptides whilst preserving their presumably beneficial NPR-A-mediated effects, including natriuretic, haemodynamic and possibly cardiac relaxant and anti-hypertrophic properties. However, as long as no such selective NPR-B receptor antagonist is available for clinical use (the closest candidate would seem to be the peptide P-19, reported by Deschênes et al. 2005), there is still a way to go to resolve this issue.

Acknowledgments Work in the author's laboratory was supported by The Norwegian Council on Cardiovascular Disease, The Research Council of Norway, Stiftelsen Kristian Gerhard Jebsen, South-Eastern Norway Regional Health Authority, Anders Jahre's Foundation for the Promotion of Science, The Novo Nordisk Foundation, The Family Blix Foundation, The Simon Fougner Hartmann Family Foundation and grants from University of Oslo. The author wishes to thank Prof. Jan-Bjørn Osnes for critical reading of the manuscript.

\section{References}

Afzal F, Andressen KW, Mørk HK, Aronsen JM, Sjaastad I, Dahl CP, Skomedal T, Levy FO, Osnes JB, Qvigstad E (2008) 5- $\mathrm{HT}_{4}$ elicited positive inotropic response is mediated by cAMP and regulated by PDE3 in failing rat and human cardiac ventricles. Br J Pharmacol 155:1005-1014

Afzal F, Aronsen JM, Moltzau LR, Sjaastad I, Levy FO, Skomedal T, Osnes JB, Qvigstad E (2011a) Differential regulation of $\beta_{2^{-}}$ adrenoceptor-mediated inotropic and lusitropic response by PDE3 and PDE4 in failing and non-failing rat cardiac ventricle. Br J Pharmacol 162:54-71

Afzal F, Qvigstad E, Aronsen JM, Moltzau LR, Sjaastad I, Skomedal T, Osnes JB, Levy FO (2011b) Agents increasing cyclic GMP amplify $5-\mathrm{HT}_{4}$-elicited positive inotropic response in failing rat cardiac ventricle. Naunyn-Schmiedeberg's Arch Pharmacol 384:543-553

Andersen GØ, Qvigstad E, Schiander I, Aass H, Osnes JB, Skomedal T (2002) $\alpha_{1}$-AR-induced positive inotropic response in heart is dependent on myosin light chain phosphorylation. Am J Physiol Heart Circ Physiol 283:H1471-H1480

Birkeland JA, Sjaastad I, Brattelid T, Qvigstad E, Moberg ER, Krobert KA, Bjørnerheim R, Skomedal T, Sejersted OM, Osnes JB, Levy FO (2007) Effects of treatment with a $5-\mathrm{HT}_{4}$ receptor antagonist in heart failure. Br J Pharmacol 150:143-152
Brattelid T, Qvigstad E, Lynham JA, Molenaar P, Aass H, Geiran O, Skomedal T, Osnes J-B, Levy FO, Kaumann AJ (2004) Functional serotonin $5-\mathrm{HT}_{4}$ receptors in porcine and human ventricular myocardium with increased $5-\mathrm{HT}_{4} \mathrm{mRNA}$ in heart failure. Naunyn-Schmiedeberg's Arch Pharmacol 370:157-166

Brattelid T, Qvigstad E, Moltzau LR, Bekkevold SV, Sandnes DL, Birkeland JA, Skomedal T, Osnes JB, Sjaastad I, Levy FO (2012) The cardiac ventricular $5-\mathrm{HT}_{4}$ receptor is functional in late foetal development and is reactivated in heart failure. PLoS One 7:e45489

Brunton LL, Hayes JS, Mayer SE (1981) Functional compartmentation of cyclic AMP and protein kinase in heart. Adv Cyclic Nucleotide Res 14:391-397

Butcher RW, Sutherland EW (1962) Adenosine 3',5'-phosphate in biological materials. I. Purification and properties of cyclic 3',5'-nucleotide phosphodiesterase and use of this enzyme to characterize adenosine 3',5'-phosphate in human urine. J Biol Chem 237:1244-1250

Christ T, Engel A, Ravens U, Kaumann AJ (2006) Cilostamide potentiates more the positive inotropic effects of $(-)$-adrenaline through $\beta_{2}$-adrenoceptors than the effects of $(-)$-noradrenaline through $\beta_{1}$-adrenoceptors in human atrial myocardium. NaunynSchmiedeberg's Arch Pharmacol 374:249-253

Christ T, Galindo-Tovar A, Thoms M, Ravens U, Kaumann AJ (2009) Inotropy and L-type $\mathrm{Ca}^{2+}$ current, activated by $\beta_{1^{-}}$and $\beta_{2^{-}}$ adrenoceptors, are differently controlled by phosphodiesterases 3 and 4 in rat heart. Br J Pharmacol 156:62-83

CIBIS-II Investigators and Committees (1999) The Cardiac Insufficiency Bisoprolol Study II (CIBIS-II): a randomised trial. Lancet 353:9-13

Cohn JN, Goldstein SO, Greenberg BH, Lorell BH, Bourge RC, Jaski BE, Gottlieb SO, McGrew F III, DeMets DL, White BG (1998) A dose-dependent increase in mortality with vesnarinone among patients with severe heart failure. Vesnarinone Trial Investigators. N Engl J Med 339:1810-1816

Colucci WS, Elkayam U, Horton DP, Abraham WT, Bourge RC, Johnson AD, Wagoner LE, Givertz MM, Liang CS, Neibaur M, Haught WH, LeJemtel TH (2000) Intravenous nesiritide, a natriuretic peptide, in the treatment of decompensated congestive heart failure. Nesiritide Study Group. N Engl J Med 343:246-253

Corbin JD, Sugden PH, Lincoln TM, Keely SL (1977) Compartmentalization of adenosine $3^{\prime}: 5^{\prime}$-monophosphate and adenosine $3^{\prime}: 5^{\prime}$-monophosphate-dependent protein kinase in heart tissue. J Biol Chem 252:3854-3861

De Maeyer JH, Straetemans R, Schuurkes JA, Lefebvre RA (2006) Porcine left atrial and sinoatrial $5-\mathrm{HT}_{4}$ receptor-induced responses: fading of the response and influence of development. Br J Pharmacol 147:140-157

Deschênes J, Dupere C, McNicoll N, L'Heureux N, Auger F, Fournier A, De Lean A (2005) Development of a selective peptide antagonist for the human natriuretic peptide receptor-B. Peptides 26:517-524

Galindo-Tovar A, Kaumann AJ (2008) Phosphodiesterase-4 blunts inotropism and arrhythmias but not sinoatrial tachycardia of $(-)$ adrenaline mediated through mouse cardiac $\beta_{1}$-adrenoceptors. $\mathrm{Br}$ J Pharmacol 153:710-720

Galindo-Tovar A, Vargas ML, Escudero E, Kaumann AJ (2009) Ontogenic changes of the control by phosphodiesterase- 3 and -4 of 5-HT responses in porcine heart and relevance to human atrial 5- $\mathrm{HT}_{4}$ receptors. Br J Pharmacol 156:237-249

Grimm M, Haas P, Willipinski-Stapelfeldt B, Zimmermann WH, Rau T, Pantel K, Weyand M, Eschenhagen T (2005) Key role of myosin light chain (MLC) kinase-mediated MLC2a phosphorylation in the $\alpha_{1}$-adrenergic positive inotropic effect in human atrium. Cardiovasc Res 65:211-220

Hussain RI, Qvigstad E, Birkeland JA, Eikemo H, Glende A, Sjaastad I, Skomedal T, Osnes JB, Levy FO, Krobert KA (2009) Activation of muscarinic receptors elicits inotropic responses in 
ventricular muscle from rats with heart failure through myosin light chain phosphorylation. Br J Pharmacol 156:575-586

Jahnel U, Rupp J, Ertl R, Nawrath H (1992) Positive inotropic response to 5-HT in human atrial but not in ventricular heart muscle. Naunyn-Schmiedeberg's Arch Pharmacol 346:482-485

Kaumann AJ (1990) Piglet sinoatrial 5-HT receptors resemble human atrial 5-HT 4 -like receptors. Naunyn-Schmiedeberg's Arch Pharmacol 342:619-622

Kaumann AJ, Birnbaumer L (1974) Prostaglandin $E_{1}$ action on sinus pacemaker and adenylyl cyclase in kitten myocardium. Nature 251:515-517

Kaumann AJ, Levy FO (2006a) 5-Hydroxytryptamine receptors in the human cardiovascular system. Pharmacol Ther 111:674-706

Kaumann AJ, Levy FO (2006b) Fading of 5- $\mathrm{HT}_{4}$ receptor-mediated inotropic responses to 5-hydroxytryptamine is caused by phosphodiesterase activity in porcine atrium. Br J Pharmacol 147:128-130

Kaumann AJ, Sanders L, Brown AM, Murray KJ, Brown MJ (1990) A 5 -hydroxytryptamine receptor in human atrium. Br J Pharmacol 100:879-885

Kaumann A, Semmler AB, Molenaar P (2007) The effects of both noradrenaline and CGP12177, mediated through human $\beta_{1}$ adrenoceptors, are reduced by PDE3 in human atrium but PDE4 in CHO cells. Naunyn-Schmiedeberg's Arch Pharmacol 375:123-131

Kjekshus JK, Torp-Pedersen C, Gullestad L, Køber L, Edvardsen T, Olsen IC, Sjaastad I, Qvigstad E, Skomedal T, Osnes JB, Levy FO (2009) Effect of piboserod, a 5- $\mathrm{HT}_{4}$ serotonin receptor antagonist, on left ventricular function in patients with symptomatic heart failure. Eur J Heart Fail 11:771-778

Läer S, Remmers F, Scholz H, Stein B, Müller FU, Neumann J (1998) Receptor mechanisms involved in the 5-HT-induced inotropic action in the rat isolated atrium. Br J Pharmacol 123:1182-1188

Levy FO, Qvigstad E, Krobert KA, Skomedal T, Osnes JB (2008) Effects of serotonin in failing cardiac ventricle: signalling mechanisms and potential therapeutic implications. Neuropharmacology 55:1066-1071

Lohse MJ, Engelhardt S, Eschenhagen T (2003) What is the role of $\beta$ adrenergic signaling in heart failure? Circ Res 93:896-906

MERIT-HF Study Group (1999) Effect of metoprolol CR/XL in chronic heart failure: Metoprolol CR/XL Randomised Intervention Trial in Congestive Heart Failure (MERIT-HF). Lancet 353:2001-2007

Molenaar P, Christ T, Hussain RI, Engel A, Berk E, Gillette KT, Chen L, Galindo-Tovar A, Krobert KA, Ravens U, Levy FO, Kaumann AJ (2013) Phosphodiesterase PDE3, but not PDE4, reduces $\beta_{1}$ and $\beta_{2}$-adrenoceptor-mediated inotropic and lusitropic effects in failing ventricle from metoprolol-treated patients. Br J Pharmacol. doi:10.1111/bph.12167

Mongillo M, McSorley T, Evellin S, Sood A, Lissandron V, Terrin A, Huston E, Hannawacker A, Lohse MJ, Pozzan T, Houslay MD, Zaccolo M (2004) Fluorescence resonance energy transfer-based analysis of cAMP dynamics in live neonatal rat cardiac myocytes reveals distinct functions of compartmentalized phosphodiesterases. Circ Res 95:67-75

Nikolaev VO, Bünemann M, Hein L, Hannawacker A, Lohse MJ (2004) Novel single chain cAMP sensors for receptor-induced signal propagation. J Biol Chem 279:37215-37218

Nikolaev VO, Bünemann M, Schmitteckert E, Lohse MJ, Engelhardt S (2006) Cyclic AMP imaging in adult cardiac myocytes reveals far-reaching $\beta_{1}$-adrenergic but locally confined $\beta_{2}$-adrenergic receptor-mediated signaling. Circ Res 99:1084-1091

Nikolaev VO, Moshkov A, Lyon AR, Miragoli M, Novak P, Paur H, Lohse MJ, Korchev YE, Harding SE, Gorelik J (2010) $\beta_{2^{-}}$ adrenergic receptor redistribution in heart failure changes cAMP compartmentation. Science 327:1653-1657

O'Connor CM, Starling RC, Hernandez AF, Armstrong PW, Dickstein K, Hasselblad V, Heizer GM, Komajda M, Massie BM, McMurray JJ, Nieminen MS, Reist CJ, Rouleau JL, Swedberg K, Adams KF Jr,
Anker SD, Atar D, Battler A, Botero R, Bohidar NR, Butler J, Clausell N, Corbalan R, Costanzo MR, Dahlstrom U, Deckelbaum LI, Diaz R, Dunlap ME, Ezekowitz JA, Feldman D, Felker GM, Fonarow GC, Gennevois D, Gottlieb SS, Hill JA, Hollander JE, Howlett JG, Hudson MP, Kociol RD, Krum H, Laucevicius A, Levy WC, Mendez GF, Metra M, Mittal S, Oh BH, Pereira NL, Ponikowski P, Tang WH, Tanomsup S, Teerlink JR, Triposkiadis F, Troughton RW, Voors AA, Whellan DJ, Zannad F, Califf RM (2011) Effect of nesiritide in patients with acute decompensated heart failure. N Engl J Med 365:32-43

Omland T, Aakvaag A, Bonarjee VV, Caidahl K, Lie RT, Nilsen DW, Sundsfjord JA, Dickstein K (1996) Plasma brain natriuretic peptide as an indicator of left ventricular systolic function and long-term survival after acute myocardial infarction. Comparison with plasma atrial natriuretic peptide and $\mathrm{N}$-terminal proatrial natriuretic peptide. Circulation 93:1963-1969

Packer M, Carver JR, Rodeheffer RJ, Ivanhoe RJ, DiBianco R, Zeldis SM, Hendrix GH, Bommer WJ, Elkayam U, Kukin ML (1991) Effect of oral milrinone on mortality in severe chronic heart failure. The PROMISE Study Research Group. N Engl J Med 325:1468-1475

Packer M, Bristow MR, Cohn JN, Colucci WS, Fowler MB, Gilbert EM, Shusterman NH (1996) The effect of carvedilol on morbidity and mortality in patients with chronic heart failure. U.S. Carvedilol Heart Failure Study Group. N Engl J Med 334:1349-1355

Ponsioen B, Zhao J, Riedl J, Zwartkruis F, van der Krogt G, Zaccolo M, Moolenaar WH, Bos JL, Jalink K (2004) Detecting cAMPinduced Epac activation by fluorescence resonance energy transfer: Epac as a novel cAMP indicator. EMBO Rep 5:1176-1180

Qvigstad E, Brattelid T, Sjaastad I, Andressen KW, Krobert KA, Birkeland JA, Sejersted OM, Kaumann AJ, Skomedal T, Osnes J-B, Levy FO (2005a) Appearance of a ventricular 5- $\mathrm{HT}_{4}$ receptor-mediated inotropic response to serotonin in heart failure. Cardiovasc Res 65:869-878

Qvigstad E, Brattelid T, Sjaastad I, Molenaar P, Birkeland JA, Andressen KW, Krobert KA, Sejersted OM, Skomedal T, Osnes J-B, Kaumann AJ, Levy FO (2005b) Rationale for treatment of heart failure by blockade of ventricular serotonin receptors appearing in heart failure. Proceedings of the 25th European Section Meeting, International Society for Heart Research, Tromso, Norway, June 21-25, 2005. Medimond International Proceedings, Bologna, Italy, pp 7-12

Qvigstad E, Sjaastad I, Brattelid T, Nunn C, Swift F, Birkeland JAK, Krobert KA, Andersen GØ, Sejersted OM, Osnes JB, Levy FO, Skomedal T (2005c) Dual serotonergic regulation of ventricular contractile force through $5-\mathrm{HT}_{2 \mathrm{~A}}$ and $5-\mathrm{HT}_{4}$ receptors induced in the acute failing heart. Circ Res 97:268-276

Qvigstad E, Moltzau LR, Aronsen JM, Nguyen CH, Hougen K, Sjaastad I, Levy FO, Skomedal T, Osnes JB (2010) Natriuretic peptides increase $\beta_{1}$-adrenoceptor signalling in failing hearts through phosphodiesterase 3 inhibition. Cardiovasc Res 85:763-772

Redfield MM, Chen HH, Borlaug BA, Semigran MJ, Lee KL, Lewis G, Lewinter MM, Rouleau JL, Bull DA, Mann DL, Deswal A, Stevenson LW, Givertz MM, Ofili EO, O'Connor CM, Felker GM, Goldsmith SR, Bart BA, McNulty SE, Ibarra JC, Lin G, Oh JK, Patel MR, Kim RJ, Tracy RP, Velazquez EJ, Anstrom KJ, Hernandez AF, Mascette AM, Braunwald E, RELAX Trial (2013) Effect of phosphodiesterase-5 inhibition on exercise capacity and clinical status in heart failure with preserved ejection fraction: a randomized clinical trial. JAMA 309:1268-1277

Riise J, Nguyen CH, Qvigstad E, Sandnes DL, Osnes JB, Skomedal T, Levy FO, Krobert KA (2008) Prostanoid F receptors elicit an inotropic effect in rat left ventricle by enhancing myosin light chain phosphorylation. Cardiovasc Res 80:407-415

Robison GA, Butcher RW, Øye I, Morgan HE, Sutherland EW (1965) The effect of epinephrine on adenosine $3^{\prime}, 5^{\prime}$-phosphate levels in the isolated perfused rat heart. Mol Pharmacol 1:168-177 
Rochais F, Abi-Gerges A, Horner K, Lefebvre F, Cooper DM, Conti M, Fischmeister R, Vandecasteele G (2006) A specific pattern of phosphodiesterases controls the cAMP signals generated by different $\mathrm{G}_{\mathrm{s}}$-coupled receptors in adult rat ventricular myocytes. Circ Res 98:1081-1088

Rossmanith GH, Hoh JF, Turnbull L, Ludowyke RI (1997) Mechanism of action of endothelin in rat cardiac muscle: cross-bridge kinetics and myosin light chain phosphorylation. J Physiol 505(Pt 1):217227

Sackner-Bernstein JD, Kowalski M, Fox M, Aaronson K (2005) Shortterm risk of death after treatment with nesiritide for decompensated heart failure: a pooled analysis of randomized controlled trials. JAMA 293:1900-1905

Saxena PR, Villalon CM, Dhasmana KM, Verdouw PD (1992) 5Hydroxytryptamine-induced increase in left ventricular $\mathrm{d} P / \mathrm{d} t_{\text {max }}$ does not suggest the presence of ventricular $5-\mathrm{HT}_{4}$ receptors in the pig. Naunyn-Schmiedeberg's Arch Pharmacol 346:629-636

Schoemaker RG, Du XY, Bax WA, Saxena PR (1992) 5Hydroxytryptamine increases contractile force in porcine right atrium but not in left ventricle. Naunyn-Schmiedeberg's Arch Pharmacol 346:486-489

Schoemaker RG, Du XY, Bax WA, Bos E, Saxena PR (1993) 5Hydroxytryptamine stimulates human isolated atrium but not ventricle. Eur J Pharmacol 230:103-105

Sutherland EW, Rall TW (1958) Fractionation and characterization of a cyclic adenine ribonucleotide formed by tissue particles. J Biol Chem 232:1077-1091

The Xamoterol in Severe Heart Failure Study Group (1990) Xamoterol in severe heart failure. Lancet 336:1-6

Vargas ML, Hernandez J, Kaumann AJ (2006) Phosphodiesterase PDE3 blunts the positive inotropic and cyclic AMP enhancing effects of CGP12177 but not of noradrenaline in rat ventricle. Br J Pharmacol 147:158-163

Verde I, Vandecasteele G, Lezoualc'h F, Fischmeister R (1999) Characterization of the cyclic nucleotide phosphodiesterase subtypes involved in the regulation of the L-type $\mathrm{Ca}^{2+}$ current in rat ventricular myocytes. Br J Pharmacol 127:65-74

Waagstein F, Hjalmarson A, Varnauskas E, Wallentin I (1975) Effect of chronic beta-adrenergic receptor blockade in congestive cardiomyopathy. Br Heart J 37:1022-1036

Waagstein F, Bristow MR, Swedberg K, Camerini F, Fowler MB, Silver MA, Gilbert EM, Johnson MR, Goss FG, Hjalmarson A (1993) Beneficial effects of metoprolol in idiopathic dilated cardiomyopathy. Metoprolol in Dilated Cardiomyopathy (MDC) Trial Study Group. Lancet 342:1441-1446

Warrier S, Belevych AE, Ruse M, Eckert RL, Zaccolo M, Pozzan T, Harvey RD (2005) Beta-adrenergic- and muscarinic receptorinduced changes in cAMP activity in adult cardiac myocytes detected with FRET-based biosensor. Am J Physiol Cell Physiol 289:C455-C461

Weninger S, De Maeyer JH, Lefebvre RA (2012) Study of the regulation of the inotropic response to $5-\mathrm{HT}_{4}$ receptor activation via phosphodiesterases and its cross-talk with C-type natriuretic peptide in porcine left atrium. Naunyn-Schmiedeberg's Arch Pharmacol 385:565-577

Weninger S, De Maeyer JH, Lefebvre RA (2013) Influence of phosphodiesteraeses and cGMP on cAMP generation and on phosphorylation of phospholamban and troponin I by $5-\mathrm{HT}_{4}$ receptor activation in porcine left atrium. Naunyn-Schmiedeberg's Arch Pharmacol. doi:10.1007/s00210-013-0855-2

Yancy CW (2004) Treatment with B-type natriuretic peptide for chronic decompensated heart failure: insights learned from the Follow-Up Serial Infusion of Nesiritide (FUSION) Trial. Heart Fail Rev 9:209-216

Zaccolo M, Pozzan T (2002) Discrete microdomains with high concentration of cAMP in stimulated rat neonatal cardiac myocytes. Science 295:1711-1715

Zaccolo M, De Giorgi F, Cho CY, Feng L, Knapp T, Negulescu PA, Taylor SS, Tsien RY, Pozzan T (2000) A genetically encoded, fluorescent indicator for cyclic AMP in living cells. Nat Cell Biol 2:25-29 